\title{
Riscos comerciais. Seguro de crédito à exportação. A Companhia Brasileira de Seguros de Crédito à Exportação - Brascex.
}

Ivan Gonçalves Passos, diretor técnico da Companhia Sul América de Seguros.
Ivan Gonçalves Passos
Para competir nos mercados internacionais é necessário fornecer condições de financiamento competitivas, além de garantias de prazo e qualidade. Concorrendo com financiamentos atrativos, o exportador automaticamente aumenta os riscos, principalmente em um cenário caracterizado por condições de instabilidade e incertezas nos campos politico e comercial, que provavelmente se estenderão por alguns anos, o que torna indispensável a existência de um sistema desenvolvido de seguros de crédito à exportação.

Também o fortalecimento da capacidade competitiva do exportador está diretamente ligado às garantias que ele possa prestar. O fornecimento de garantias sólidas, como as do seguro, é fundamental e implica a necessidade de um sistema segurador dinâmico na área internacional, para auxiliar o exportador. Sem dúvida, a aceleração das exportações brasileiras superou à do segurador em operações no exterior, quer no crédito, quer na garantia.

Criado por lei em março de 1962, substituído em julho de 1965 e regulamentado em novembro do mesmo ano, o seguro de crédito à exportação teve sua primeira apólice de riscos comerciais emitida em 1968 , por uma seguradora privada, concomitantemente com o primeiro certificado de riscos políticos emitido pelo Instituto de Resseguros do Brasil - IRB (naquela data, o Brasil se tornou o primeiro país, dentre os participantes da Associação Latino-Americana de Livre Comércio - ALALC, a operar em riscos de exportação com o objetivo de prevenir prejuízos).

A aplicação do seguro de crédito é hoje por demais complexa, pois o segurador, como instituição prestadora de seryiços, tem que estar habilitado a realizar cadastros para avaliação econômicofinanceira dos importadores, garantidos, para estabelecimento de limites e, conseqüentemente, para auxiliar o exportador na seleção dos seus clientes. O segurador deverá também contar com um siste- ma eficiente de cobrança dos eventuais inadimplentes, o que permitirá a redução de seus prejuízos e, no mesmo passo, a operação com taxas mais reduzidas, diminuindo o custo do exportador.

A existência de tal sistema somente é viável com a massificação do seguro de crédito e concentração dos serviços em um processo de sinergia. No atual modelo brasileiro, onde os seguros de riscos comerciais são emitidos dispersamente por todas as seguradoras, as despesas para operação eficiente de seguros de crédito à exportação não são compensadoras, e nenhum segurador se propõe a investir num sistema instável, inclusive com a perspectiva de extinção pela criação de seguradora única para o ramo.

Constituída de capitais públicos e privados pela Lei n. 6.704/79, ainda pendente de regulamentação, a Companhia Brasileira de Seguros de Crédito à Exportação - Brascex representará a concentração de esforços para minimizar os riscos do exportador e do segurador.

Eis a evolução de alguns números relativos à cobertura de riscos comerciais: em 1978, 12\% das exportações brasileiras, em valor, foram seguradas, índice que desceu para $10 \%$, em 1980. A quantidade de apólices emitidas no mesmo período evoluiu de 2.174 para 7.450 apólices. No mesmo passo, o valor médio segurado por apólice caiu de 703 para 294 mil dólares, o que demonstra aumento de utilização do seguro por seguradoras menores, provavelmente em função da obrigatoriedade do seguro para alguns financiamentos à exportação. O risco político apresentou em 1979 sinistrabilidade de 231\%. Embora sem números exatos, sabe-se que os resultados de 1980/1981 foram ainda piores. Dado que certas condições de instabilidade política criam novos mercados exportadores, é necessário compatibilizar o interesse político com o econômiço. Não interessa, afinal, exportar para receber do segurador brasileiro. 
O outro fator - competitividade - necessário ao exportador (oferecimento de garantias de concorrência e execução - BID e performance bond), tem normas bem-definidas e as condições brasileiras são normalmente aceitas internacionalmente, mesmo que exista algum tipo de cláusula recusável, pois os seguradores brasileiros geralmente adaptam as condições, de tal maneira que os países admitem os novos termos sem nenhuma dificuldade. $\mathrm{O}$ apoio do seguro, entretanto, não se restringe a esses ramos. Operar em mercados novos com diversificação legislativa e geográfica implica novos riscos para os quais o exportador tem que estar preparado sob pena de comprometer seu investimento. Neste campo, aliás, o mercado brasileiro evoluiu bastante, podendo atender ao exportador na proteção dos seus riscos físicos, pessoais e de responsabilidade. No ramo da engenharia, por exemplo, podem ser cobertos fenômenos de força maior, como inundações, terremotos, etc. E as condições brasileiras são bastante flexíveis e adaptáveis às necessidades do exportador. Convém observar, entretanto, que o Brasil, através do Banco do Brasil, não vem exigindo, nos contratos de financiamento, seguro por segurado- ra brasileira, como o fazem, de seu lado, para proteger o segurador nacional, os países desenvolvidos, de que é exemplo a França: a hidrelétrica de Tucuruí, financiada por aquele país, teve os seguros colocados obrigatoriamente na França, em detrimento do segurador brasileiro. Um caso positivo de minha experiência na África: O Banco do Brasil financiou $80 \%$ de uma estrada, mas sob exigência contratual que a obra fosse segurada, por seguradora brasileira ou de primeiro nível daquela região.

Daí, as seguintes sugestões ora elevadas à consideração dos responsáveis pela política de seguros à exportação neste país: regulamentação da Brascex, que colocará à disposição do exportador uma empresa especializada em seguros de crédito à exportação, aliviando-o das dificuldades hoje existentes, desde que os riscos comerciais sejam emitidos por várias companhias privadas e os riscos políticos pelo Instituto de Resseguros do Brasil, tornando-se antieconômico; em caso de sinistro, acionar o importador inadimplente; norma operacional do Banco do Brasil consistente em obrigar a contratação de seguros em seguradoras brasileiras sempre que financiar projetos no exterior.

\section{Riscos: responsabilidade, natureza e extensão}

Mário Palmeira Ramos da Costa, advogado do Instituto de Resseguros do Brasil

Os riscos não são do segurador; este apenas cobre os riscos: os riscos são do exportador. De acordo com a lei brasileira, todo seguro de bens e servicos produzidos no Brasil tem que ser realizado no Brasil - essa a política do Instituto de Resseguros do Brasil, desde sua instituição em 1939. Mas o exportador precisa apresentar a sua necessidade de coberturas ao segurador, para que este a encaminhe a quem de direito, porquanto o contrato de seguro no Brasil é estabelecido pelo poder público através da Superintendência de Seguros Privados - Susep, órgão que estabelece o tipo de cobertura e as condições em que irá ser concedida.

Os riscos são vários; nem todos, porém, concernem a seguro, como o caso dos juros, que é de natureza eminentemente financeira. Ehá modalidades novas que reclamam coberturas novas: energia nuclear, poluição e outros que vão surgindo com o desenvolvimento econômico e tecnológico, que o

\section{Mário Palmeira Ramos da Costa}

seguro forçosamente reflete. Em qualquer caso, entretanto, é o segurado que deve procurar o segurador, assim como é o doente que deve procurar o médico.

Quanto ao seguro de crédito à exportação lque surgiu a partir da Segunda Guerra Mundial como forma de facilitar a exportação e vencer a concorrência, garantindo o crédito que o exportador fazia ao importador), nasceu no Brasil com a Lei . $^{\circ} 4.678$, de 1965 , regulamentada pelo Decreto n. 57.286 , também de 1965, vigentes até hoje. Cobre vários riscos: inadimplência contratual; prejuízos de negócios não-concluídos, embora adotados os empreendimentos necessários (por exemplo, desistência, pelo comprador de fabricação iniciada); má instrução do cadastro do importador (registram-se nesse sentido vários sinistros, inclusive, entre nós, e ajuizados, dada a situação de pré-insolvência do exportador já ao tempo do fornecimento do crédito e do segurol; 